\title{
O espectador-internauta: desafios em tempos de transição
}

\section{Audience-Internet users: challenges in times of transition}

Gisela G. S. Castro I xxx@gmail.com

Docente e pesquisadora do Programa de Pós-Graduação em Comunicação e Práticas de Consumo da ESPM-SP.

\section{Resumo}

O texto apresenta resultados parciais de pesquisa sobre transmidiação em Cheias de Charme para a rede Obitel-Brasil. Entede-se que nossa teledramaturgia simultaneamente interpreta e interpela o espectador-internauta, participando igualmente de sua constituição e da consolidação do uso das novas mídias e fomentando a ideia da desenvoltura nas plataformas digitais como requisito básico em nossos dias.

Palavras-Chave: Comunicação e consumo; telenovela; transmidiação.

\section{Abstract}

This paper presents parcial results from ongoing research on transmediation in Brazilian telenovela Cheias de Charme for the Obitel-Brazil network. It argues that the viewer who is also an internet user is both addressed and shaped by our teledramaturgy as it helps to consolidate the use of new media and, at the same time, to foster the idea that mastering digital platforms is an essential asset in today's world.

Keywords: Communication and consumption; telenovela; transmediation. 


\section{Introdução}

Entendendo-se a comunicação como bios (SODRÉ 2003) ou nos termos da ecologia conforme Scolari (2008), nosso ambiente comunicacional se caracteriza pela convergência de meios e a mobilidade das plataformas midiáticas. A crescente apropriação das redes sociais digitais para circulação e produção compartilhada de conteúdo enseja a urgente necessidade de cartografar e analisar os agentes sociais demandados pela chamada nova economia digital. A transformação do receptor em usuário de mídia favorece modos de interação, como o espectador que prolonga na internet sua experiência com a programação da TV. A constituição do espectadorinternauta faz parte das atuais estratégias midiáticas.

Fruto de um projeto de pesquisa em andamento junto ao Núcleo ESPM para a rede Obitel-Brasil, o presente trabalho tem como objetivo discutir a emergência desse tipo de interator. São analisadas algumas das estratégias que contribuem para fomentar a conjugação entre televisão e internet, o manejo das múltiplas telas e a participação do telespectador enquanto fã, parceiro e crítico da programação em questáo. Trata-se de um interator conectado que manipula simultaneamente diferentes plataformas comunicacionais fusionando os tênues limites entre o público e o privado, o trabalho ou as tarefas escolares e o lazer, dando origem a uma mescla pessoal e idiossincrática cujos principais componentes são comunicação, entretenimento e consumo.

Comunicação, consumo e entretenimento estão na base da experiência contemporânea de mundo. Castells (2009) compreende o sistema midiático como um grande negócio. A globalização, a desregulamentação e a expansão de redes telemáticas são tendências que transformam o mundo dos negócios e também as operações da mídia. O entretenimento é a base da programação midiática devido à sua capacidade e seduzir grandes audiências. Como componente principal do atual sistema midiático figura o entretenimento inteiramente baseado na internet e nos programas de software. De fato, os processos de globalizaçáo de mercado e o surgimento da informática e da microeletrônica atuam na reconfiguraçáo de nossas práticas quotidianas. Esta seria, portanto, uma sociedade do infoentretenimento, sendo que denominaçáo aponta de modo exemplar para a fusão dos elementos característicos do tempo presente.

O estudo das estratégias de produção midiática revela que o entretenimento se apresenta como lógica dominante (CASTELLS 2009, CASTRO 2012a, 2012c), contagiando áreas tão diversas quanto o jornalismo, a educação e mesmo a política. Os neologismos tão bem descritos por Bosshart e Hellmüller (2009) refletem com a ampla disseminação do entretenimento nas dinâmicas do infotainment, do edutainment, do politainment e afins. Peça central no lazer cotidiano da grande maioria de nossa população, a televisão brasileira não é indiferente a essa lógica. Ao lado da presença quase universal da televisão, a crescente penetração da internet nos domicílios brasileiros enseja modificaçóes nas formas de lazer, nas práticas de consumo e nos modos de sociabilidade os quais necessitamos conhecer e analisar. $\mathrm{O}$ esforço aqui empreendido visa 
contribuir para acompanharmos criticamente os deslocamentos em curso na figura do telespectador conectado a diferentes telas ao mesmo tempo: o espectador-internauta.

No novo ecossistema midiático, o espectador-internauta apresenta, por exemplo, importantes desafios em termos de economia da atenção. Ao se desdobrar simultaneamente em múltiplas tarefas, utiliza um tipo de concentração difusa e errante que comumente não se fixa a ponto de levá-lo a uma fruição em profundidade de um só conteúdo ou plataforma. Por outro lado, esse tipo de imersão favorece o estabelecimento de conexóes e a produção de novas combinaçóes entre conteúdos dando origem a formatos típicos da cultura digital.

A capacidade de agência desse espectador que não apenas produz e distribui conteúdo como também interage com os meios em tempo real, de certo modo desestabiliza os roteiros tradicionalmente utilizados na cena midiática e convoca os produtores de conteúdo a conceberem novas estratégias que aos poucos se impóem neste cenário de convergência de meios e de narrativas. Interpelar e engajar o espectador como interator é cada vez mais importante não somente em termos propriamente comerciais como também para conferir uma roupagem contemporânea a formatos e gêneros midiáticos mais tradicionais, como no caso da telenovela, preservando seu interesse e relevância em tempos de convergência e transmidialidade.

Nossa discussão sobre o telespectador conectado e seduzido pelas tecnologias de comunicação, sociabilidade e negócios, toma como base o mapeamento das estratégias de transmidiação adotadas pelos produtores de Cheias de Charme (Rede Globo, 2012), bem como o monitoramento dos conteúdos relacionados a esse universo ficcional que circularam em redes sociais abrigadas no Facebook e no YouTube. A escolha desses sites de rede social se justifica por serem majoritariamente utilizados pelos internautas brasileiros, cujo tempo médio de navegação online é dos mais altos do mundo. A observaçáo de caráter netnográfico fornece elementos para a reflexão sobre os modos de interação entre a maior emissora de televisão brasileira e seu público, em torno da telenovela.

\section{A TV e a segunda tela}

Jesús Martin-Barbero (2008) destaca as tecnicidades como processos decorrentes das mudanças trazidas pelas dinâmicas e práticas da cibercultura no domínio das subjetividades. Sem incorrer no determinismo tecnológico, o autor concebe as tecnicidades como transformaçóes na sensibilidade, novas maneiras de percepção e linguagem surgidas a partir da apropriação social das redes digitais interativas. Entendemos as tecnicidades como fator-chave na modulação das interações nas redes sociais digitais e na constituição do espectador-internauta. Como parte das características do contemporâneo, ressalta-se o consumo individual e fragmentado dos meios de comunicação.

Scolari (2011) explica a crescente fragmentação textual e das audiências ressaltando que o consumo sincrônico proposto pelo broadcasting tende a explodir em inúmeras de situaçôes individuais assincrônicas como no fenômeno da segunda tela, crescente em todo o mundo e também no Brasil (SARKIS, 2013). Mais e mais 
brasileiros conectados à internet assistem à TV ao mesmo tempo em que usam tablets, smartphones e notebooks. Dados divulgados pelo jornal diário Folha de $S$. Paulo (2013), indicam que um em cada seis brasileiros navega na internet enquanto assiste à televisão. Desse montante, 59\% praticam diariamente essa modalidade de fruição combinada. As telenovelas são os programas mais comentados pelos internautas brasileiros (40\%), seguidas de noticiários (36\%) e esportes (33\%). O Facebook tem no Brasil sua segunda maior rede de usuários, atrás apenas dos Estados Unidos. Para que se possa dimensionar o quanto a prática de comentar na rede a programação da TV está hoje disseminada no País, o último capítulo da telenovela Avenida Brasil (Rede Globo, 2012) teve maior repercussão no Facebook do que o SuperBowl em seu país de origem (CRUZ, 2013).

Chao (2013) indica o Brasil como a capital mundial das mídias sociais. No caso da televisáo, esta disposição para estabelecer relaçóes online por meio de comentários e outros tipos de interaçáo nas redes digitais pode funcionar também para informar sobre a programação do momento e aumentar os índices de audiência dos programas enfocados. De certo modo, a segunda tela pode conferir nova vida à grade de horários televisiva que estaria perdendo sentido diante da oferta dos conteúdos selecionados conforme o gosto e a conveniência do telespectador. Ao analisarem novos tipos de interação entre os polos de produção e recepção das telenovelas brasileiras, Antonacci e Baccega (2012) constatam que agora espraiada para as mídias digitais, a teleficção convive com espectadores que também criam conteúdos que dialogam com a narrativa principal. $\mathrm{O}$ fenômeno produz desdobramentos em ambos os polos: de um lado, produtores realizaram açôes diversas para assegurar sua presença no ambiente digital e tentar garantir manutenção de público para a programação da TV. De outro, consumidores encontram um novo cenário para consumir produtos midiáticos como a tradicional telenovela.

Em contraste com a alegação marcadamente mercadológica de que o atual consumidor de mídia estaria deixando de ser 'mero' receptor para assumir o papel de co-produtor de conteúdo; vale reforçar que a complexidade do processo de recepção já foi amplamente evidenciado pelos estudiosos muito antes da entrada em cena das tecnologias digitais. A veterana Baccega (2009) concebe o receptor da comunicação como um sujeito ativo que não apenas participa da produção de sentido das mensagens da mídia, como também inclui essas ressignificaçôes no conjunto de suas práticas culturais.

Ao analisarem a produção de conteúdo nas redes digitais por parte do público - notadamente dos fấs de Cheias de Charme - Torreglosa e Jesus (2012) destacam que a telenovela gera uma relação única, diferente das séries estrangeiras ou de qualquer outra forma de manifestação do público que assiste à televisão. Ao tratarem do diálogo que se estabelece entre a produção trama na emissora e o conteúdo produzido pelos fãs na web, os autores levantam uma pertinente questão: até que ponto a profusão de informações, as várias formas de uso midiático, a possibilidade de produção de conteúdos e as novas configuraçóes dos discursos na web reforçam a institucionalidade unidirecional ou provocam o senso crítico autônomo e independente? 
Como se pode observar durante a pesquisa empírica aqui apresentada, os comentários sobre a telenovela podem apresentar certo grau de criticidade em relação ao próprio gênero ao fazerem alusóes ao andamento da narrativa, a diferentes aspectos da produção ou ao desempenho de determinado ator ou atriz, por exemplo. Esse é o caso do comentário recolhido no Facebook e apresentado aqui em versão reduzida e com a grafia original característica desse tipo de postagem: «Tudo bem que novela é ficção, mas os autores devem ter responsabilidade com a mensagem que transmitem ao público; não é possível que o autor dessa novela vá continuar tratando como normal um vagabundo como SANDRO servir de exemplo para o filho (...) Quando SANDRO aparece, minha TV muda o canal!»

Outros tipos de comentários dialogam com as situaçóes criadas na trama, ecoando certos bordóes e reforçando características da narrativa. Exemplos coletados durante a pesquisa ilustram essa categoria de comentário: «Ai que nojo desse Sandro, ninguém merece esse homem, Penha tem que ficar com o dr. Oto werneck....» Esta postagem com link para cena do beijo entre os personagens Cida e Elano recebeu 4766 compartilhamentos: "Cida ainda vai pensar se fica com Elano ou não em Cheias de Charme? Louca, né? Quem queria um príncipe desse, COMPARTILHA!!!!» Por fim, apresenta-se postagem recebeu 709 cliques na opção 'curtir': «CORRE porque começou Cheias de Charme!!! (...) Quem tá grudado na TV, CURTE aí!!!»

É imprescindível entender esta telenovela no contexto da nova configuração populacional brasileira. Metade dos acessos à internet é atualmente efetuada pela classe C, que já representa mais de $50 \%$ de nossa população total. De fato, o notável movimento de ascensão social de segmentos menos favorecidos nas últimas décadas é um dos mais importantes indicadores do crescimento do País, reforçando sua posição de destaque no bloco internacional de estados emergentes.

Vale lembrar que no complexo e excludente ecossistema comunicacional atual, destaca-se o crescimento do acesso aos meios digitais por parte das classes menos favorecidas. A promessa de transformar cada brasileiro em consumidor transformou-se em plataforma de governo. Evidenciando a centralidade do consumo nas dinâmicas da atualidade, políticas sociais que estimulam o acesso ao microcrédito visam promover maior igualdade social no país.

Se consideramos a relevância do internauta brasileiro nas redes digitais lado a lado com a necessidade por parte dos responsáveis pela narrativa aberta das telenovelas em receber continuamente feedback do público, as interaçóes online entre os espectadores-internautas funcionam como grupos focais em tempo real que, embora sem relevância estatística, ajudam a conhecer o diversificado segmento de público composto pela nova classe média.

\section{O (in)discreto charme da periferia}

Tomando emprestado o título do clássico filme de Buñuel para formar um sugestivo jogo de palavras com a telenovela em questáo, vale discorrer brevemente sobre os esforços da teledramaturgia da maior emissora brasileira em dirigir-se de modo mais direto à faixa da população que se tornou predominante nos últimos dois anos: a classe C. O caráter realista da narrativa ficcional que se desenrola na 
tela é uma importante marca da teledramaturgia brasileira. A telenovela congrega enormes audiências justamente por sua ressonância com a realidade social. Embora seja o produto midiático de maior penetração junto ao grande público, o padrão Globo de qualidade ditou a opção por uma estética sofisticada, o que de certa forma impunha à teleficção o universo simbólico característico das classes mais abastadas. Para promover a identificação e para cativar o público das classes emergentes, as duas principais novelas da Rede Globo em 2012 inovaram ao destacarem como centrais figuras oriundas da periferia da cidade do Rio de Janeiro. Cheias de Charme e Avenida Brasil retratam com propriedade a ascensão da classe $\mathrm{C}$ por meio de seus personagens, representaçóes de uma classe que deixou de ser coadjuvante e passou a ser protagonista. (TARAPANOFF e FERNANDES, 2012).

Apesar da liderança da Rede Globo no cenário midiático brasileiro, tanto em termos de audiência quanto por sua pujança como produtora de conteúdo, há tempos não eram registrados os expressivos índices de audiência conquistados por Cheias de Charme e Avenida Brasil. Não por acaso, a TV é a maior fonte de entretenimento da parcela da população que protagoniza ambas as tramas. Releituras contemporâneas da Gata Borralheira, essas novelas abordaram a dura vida das empregadas domésticas, dos demais habitantes das favelas e dos subúrbios cariocas cortados pela avenida que dá nome a uma dessas produçôes. Ao comentarem sobre a cultura da periferia carioca, as narrativas trouxeram para o prime time da televisão brasileira seus idiossincráticos modos de ser e de viver, além de manifestaçôes culturais voltadas para esse público, além de artistas populares desconhecidos pelas classes mais favorecidas.

Em ambos os casos, procurou-se aproximar do público-alvo ao apresentar o sonho de ascensão da classe C. Se, na primeira trama, o sucesso na carreira artística sinalizava o imaginário da mobilidade social, o craque de futebol ocupou essa função simbólica na segunda. Cada uma a seu modo, as narrativas criticaram a futilidade consumista e a precariedade afetiva e moral associadas aos estilos de vida predominantes das zonas nobres da cidade. Enquanto se dedicavam ao trabalho, aos estudos, ao esporte ou à carreira artística de modo a vencer na vida, esses personagens icônicos permaneceram fiéis às suas origens humildes, sendo apegados à família, às tradiçôes religiosas, à convivência com os vizinhos, aos arraigados valores morais e aos seus gostos e preferências em termos de culinária, indumentária, decoração, música, atividades de lazer etc. Como de costume, o repúdio aos métodos inescrupulosos de "se dar bem" na vida esteve presente.

A imagem abaixo mostra o trio de protagonistas de Cheias de Charme formado por Maria do Rosário (Rosário - Leandra Leal); Maria da Penha (Penha - Taís Araújo); e Maria Aparecida (Cida - Isabelle Drummond). As três personagens são representações típicas de uma figura presente no imaginário social sobre a classe C: a mulher que batalha, passa por dificuldades, mas no final vence devido à sua coragem, força de vontade e determinação (Tarapanoff e Fernandes, 2012). Nesta imagem em que os uniformes das domésticas trazem a estampa da borboleta - importante elemento simbólico na trama - as graciosas Marias interpretam, divertidas, o seu primeiro grande sucesso musical. 


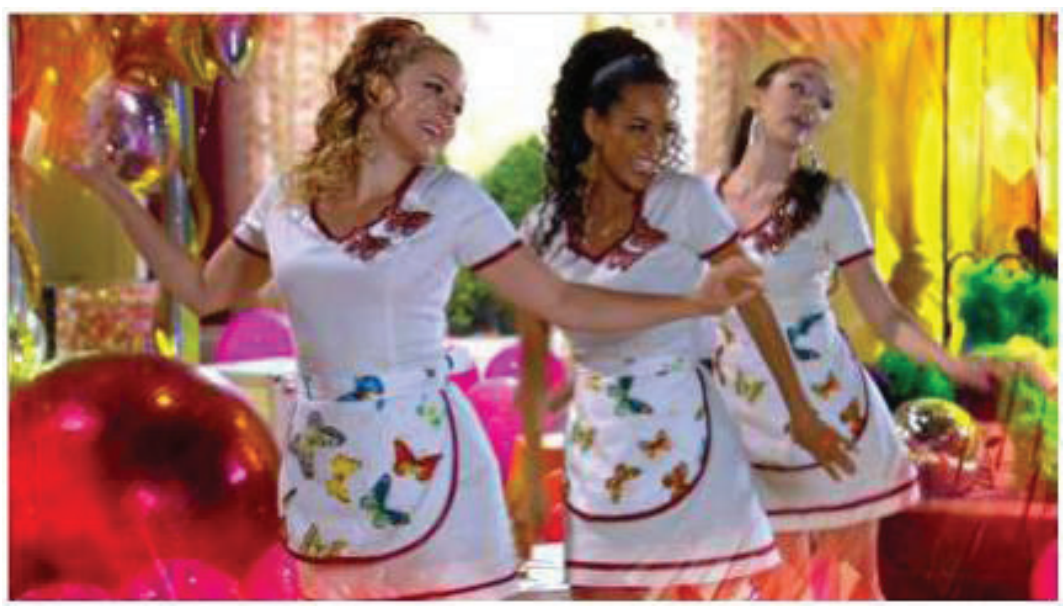

Figura 1: Cena do videoclipe Vida de Empreguete

Fonte: http://tvg.globo.com/novelas/cheias-de-charme/index.html (acesso 30 de abril, 2013)

O lançamento oficial de Vida de Empreguete se deu na internet, conforme anunciado no final do capítulo no qual foi inserido na rede por um dos personagens da trama. Como descrevi em trabalhos anteriores (Castro 2012, 2012b) esta complementaridade inovadora e muito bem sucedida entre a narrativa televisiva as plataformas digitais rendeu um número recorde de visualizaçóes do clipe apenas nas 24 horas que antecederam sua exibição no capítulo seguinte. $\mathrm{Na}$ sequencia, música e coreografia serviram de base para a elaboração de paródias e outros tipos de produção criativa nas redes sociais.

Chegando ao final da trama, já firmemente estabelecidas como artistas, as glamourosas ex-domésticas estrelam o clipe Nosso Brilho. O sucesso das charmosas empreguetes junto ao público transcendeu as fronteiras da novela e se converteu em estratégias crossmedia. As músicas atingiram as paradas de sucesso, ocasionado a participação do trio em programas de variedades e shows patrocinados pela emissora

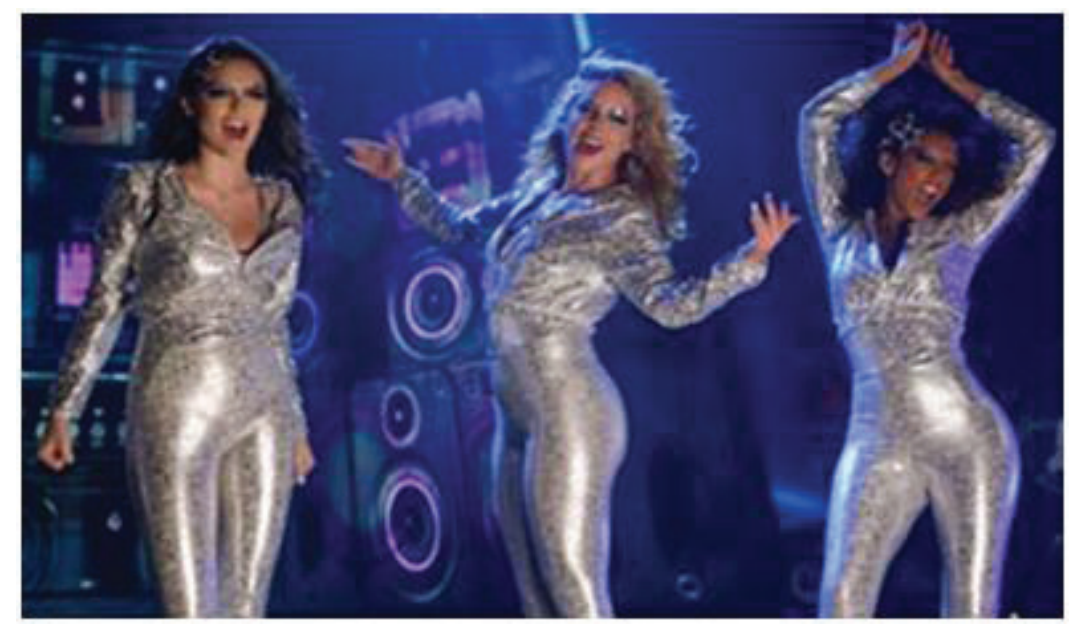

Figura 2: Cena do videoclipe Nosso Brilho

Fonte: http://tvg.globo.com/novelas/cheias-de-charme/Fotos/ (acesso em 30 de abril, 2013) 
Na transmidiação de Cheias de Charme destaca-se, por exemplo, a presença do rádio, das redes sociais e da música como elementos constitutivos da narrativa televisual. Em diversas situaçóes o público foi chamado a participar de campanhas originadas na novela que envolveram outros programas da grade da Globo. Promoveu-se, ainda, a hibridização entre ficção e realidade com a atuação de artistas consagrados do meio musical em cena com as protagonistas.

\section{Transmidiação e pedagogia social na telenovela}

A No chamado marketing social, um elemento que vincula a telenovela brasileira a questóes candentes na agenda social, a delicada questáo envolvendo os direitos do trabalhador doméstico comparece em diversas situaçóes da trama de Cheias de Charme. As disputas jurídicas são discutidas no escritório de advocacia que faz parte da trama, na qual predomina o viés assumidamente favorável às domésticas. Em outro exemplo de hibridização entre ficção e realidade, a página oficial da novela exibe uma sessão assinada pelo escritório Amaro Werneck. Nesta sessão, a personagem de Taís Araújo esclarece em vídeo sobre a importância da carteira assinada. Para se ter uma ideia de como é espinhoso o tema, apenas em 1973 a legislação brasileira assegurou às domésticas o direito à carteira de trabalho assinada. Mudança implementada quatro décadas depois, em 2013, levou nossa justiça a finalmente conceder à categoria o direito ao regime de oito horas diárias de trabalho e ao pagamento de horas extras. Segmentos mais conservadores tem gerado polêmica visando tornar inócuas as novas determinaçóes anunciadas algum tempo depois da telenovela ter chegado ao fim.

Ao examinarmos as lógicas de produção e os modos de endereçamento em Cheias de Charme, buscamos compreender as maneiras pelas quais nossa teledramaturgia convoca e participa das interaçóes nas redes sociais digitais. Ao interpelar o espectador que é também usuário de internet, a telenovela promove certo tipo de pedagogia social - notadamente junto ao público que tem a televisão como principal opção no lazer cotidiano - que preconiza a participação no mundo digital como desejável e mesmo indispensável na atualidade.

Sendo a telenovela um produto voltado para o grande público, as intenções de seus produtores ao inserir elementos da cultura digital na teleficção podem ser compreendidas por meio de um duplo viés. Para o telespectador que já é usuário de mídias digitais, busca-se a sua identificação ao trazer para a novela a representação de práticas do cotidiano. Já para o telespectador não iniciado, o passo a passo da interação com essas ferramentas é didaticamente encenado. Trata-se, portanto, de simultaneamente interpretar e interpelar o espectadorinternauta. Participa-se igualmente de sua constituição e da consolidação do uso das novas mídias no seu dia a dia.

Scolari (2008) denomina hipermediação ao processo de intercâmbio, produção e consumo simbólico desenvolvidos em um entorno caracterizado pela grande quantidade de sujeitos, meios elinguagens interconectados tecnologicamente e de maneira reticular entre si. Considerando-se o caráter aberto da narrativa 
ficcional da telenovela, entende-se que a participação ativa do receptor nas hipermediações não constitui uma inovação do digital. Segundo Baccega (2012), as principais transformaçóes seriam a velocidade e a capilaridade do conteúdo gerado pelo receptor atual, que tem condiçóes de atingir um número quase incalculável de pessoas reunidas em função de gostos e interesses nas redes digitais.

Em entrevista concedida a um importante periódico brasileiro, Scolari (2011) constata que tão logo termina a emissão de um episódio de uma dada série televisiva, os fóruns e páginas web entrem em estado de agitação. Os espectadores discutem o texto que acabaram de ver, analisam suas possíveis continuaçóes e debatem sobre os personagens e a trama do episódio. Para o autor, a construção de mundos possíveis em muitos casos deixou de ser um processo individual para converter-se em um processo coletivo que se desenvolve nas redes sociais.

Ao ser perguntado sobre como esse processo se aplicaria no caso da telenovela, o autor pondera que, assim como qualquer outro gênero, a telenovela deverá fazer frente a importantes transformaçóes de ordem geracional. Ao indagar de que modo a telenovela será sintonizada pelas novas geraçóes crescidas no calor das redes sociais, dos videojogos e do YouTube, o autor aponta as narrativas transmidiáticas como um possível caminho para o futuro do gênero.

A produtividade online do telespectador-internauta mereceu criteriosa análise por parte do pesquisador Mark Andrejevik (2008). Sua posição problematiza, sobremaneira, alegaçóes de certo modo ingênuas acerca da produção coletiva das narrativas transmidiáticas. Sua argumentação enfatiza a ambiguidade deste tipo de produção. Por um lado, comunidades vinculadas a programas de televisão têm como pontos positivos seus modos de sociabilidade e o prazer proporcionado por interaçóes divertidas, instigantes e criativas nas redes sociais. Por outro lado, o caráter criativo dessas interaçóes funciona como atrativo para cooptaçáo por parte dos produtores desses programas televisivos. Para além do caráter lúdico, esta interatividade pode ser considerada como modalidade de trabalho não reconhecido e não remunerado.

Outro aspecto problemático diz respeito à aparente autonomia do telespectador para se manifestar livremente na internet. Ao invés de funcionarem como arenas públicas para o exercício das faculdades críticas, o compartilhamento de conteúdo protegido nas redes digitais é cerceado por acordos de ordem mercadológica (Candido, 2011), sendo que as interaçóes nas redes sociais funcionam como valor agregado ao promoverem o interesse e a fidelização dos telespectadores.

Conforme constatam acertadamente Torreglosa e Jesus (2012), a mediação da telenovela brasileira, principalmente na Rede Globo, é uma malha densa, ampla e espetacular que visa fornecer a sua audiência tantas camadas de tramas, sites, cenas de bastidores e áreas de aderência que criam com eficiência uma modalidade de espectador fiel, apaixonado e comprometido com o sucesso 
da trama: o fã da telenovela. Cristaliza-se esta figura em suas tramas ao passo que são fornecidas ferramentas próprias e controladas para que os fấs possam participar da construção desse universo ficcional.

$\mathrm{Na}$ contramão das práticas de livre produção e compartilhamento comuns nas redes digitais, a Globo atua judicialmente para coibir nas redes digitais a circulação de conteúdo oriundo de sua programação protegida por leis de direito autoral e propriedade intelectual. A emissora estaria especialmente preocupada com a audiência de seus canais oficiais ao não permitir que os internautas acompanhem suas telenovelas apenas pelo YouTube, serviço de hospedagem eu se tornou uma referência em matéria de vídeos (Candido, 2011). Concebido como principal ambiente virtual de integração entre a emissora e seu público, o portal Globo.com estabelece um jogo de complementaridade com a programação diária da Rede Globo e pretende ser o local onde se encontre todo o tipo de informação sobre o conteúdo da marca. Assinantes do portal podem acessar os capítulos da novela em versão integral. Também utilizando o sistema de assinaturas, o serviço Globo.TV+ fornece na íntegra conteúdos veiculados na televisão para tablets, smartphones e computadores.

\section{Considerações em incertezas}

Em seu último trabalho, Jenkins (2013) focaliza a produção de conteúdo amplamente distribuído nas chamadas mídias sociais. A transmissão (broadcast) unidirecional característica da comunicação de massa identifica como valor aquilo que o autor denomina como stickiness ou grude, numa tradução livre. Trata-se da tendência de certos conteúdos para permanecer na memória. Para a comunicação em rede, o valor estaria na capacidade de se espraiar em várias plataformas: atributo denominado spreadability. Para o autor, as narrativas classificadas como transmidiáticas exibem sobremaneira esta última capacidade.

Problematizando essa taxonomia que desconsidera as especificidades culturais e toma os gêneros narrativos e os modos de comunicaçáo como semelhantes, destacamos as disparidades entre a novela brasileira e sua congênere estadunidense. Em nossa cultura, as telenovelas da Rede Globo ocupam posição de destaque no horário nobre da televisão aberta, congregando um público fiel e atingindo expressivos níveis de audiência. Do ponto de vista dos produtores dessas telenovelas, a transmidiação não se configura como um recurso para salvar um gênero decadente conforme preconizam Ford, De Kosnik e Harrington (2013) em relação às soap operas norte americanas.

Ao integrar as novas tecnologias digitais na trama das telenovelas, a Globo contribui para difundir a percepção de que são indispensáveis ao tão propalado ideal da qualidade de vida, em nome do qual se gera gastos por vezes incompatíveis com níveis de renda de consumidores mais vulneráveis às persuasivas retóricas do marketing. Desse modo, constituise o telespectador usuário de ferramentas digitais de comunicação, fomentando a ideia da desenvoltura nas plataformas digitais como requisito básico em nossos dias. 
Especialista em marketing, Leone (2013) considera protagonistas as comunidades criativas de consumidores engajados no universo online. Para ele, atualmente a geração de conteúdos e valor resulta do compartilhamento entre usuários (classificados como prosumers no jargão dos profissionais do mercado) e digital leaders de redes digitais organizadas em torno de marcas, serviços ou produtos. Novas configuraçóes de poder estariam na base de práticas como a cocriação, a customização em massa e o crowdsourcing, cuja descrição foge ao escopo da discussão.

A promessa da participação virtual no processo produtivo incita o consumidor a adotar o ponto de vista dos produtores, contribuindo para parametrizar a produção do público internauta segundo as lógicas do mercado e facilitando a conversão do feedback produzido nas redes sociais em informação relevante para as estratégias de marketing. Coerente com os preceitos do empreendedorismo neoliberal, a retórica do consumer empowerment subentende o imperativo de tornar-se sempre mais bem informado e eficiente, assumindo responsabilidade pelo constante aprimoramento pessoal.

Voltando o foco para as interaçôes do público nas plataformas digitais que complementam a programação da TV, Andrejevik (2008) salienta que essa participação promove a fidelização do espectador-internauta, além de levá-lo a assumir em parte o trabalho de tornar o programa em questão mais interessante, inteligente e divertido. A utilização das redes sociais digitais para calibrar o andamento de determinado programa como a telenovela, por exemplo, favorece ainda a disseminaçáo viral de campanhas promocionais e ações de buzz marketing segundo os interesses de produtores e patrocinadores.

Produção emblemática e inovadora, Cheias de Charme foi analisada em estimulante variedade de estudos apresentados no maior evento realizado pelo campo acadêmico da Comunicação do Brasil em 2012. Trabalhos elaborados por pesquisadores como Antonacci e Baccega; Mascarenhas e Tavares; Rego; Tarapanoff e Fernandes; Torreglosa e Jesus; dentre outros a própria autora dessas linhas, evidenciam a relevância desse produto cultural e suas ressignificaçóes no atual contexto midiático em transição.

Toma-se o consumo como vetor privilegiado para refletir sobre a crescente penetraçáo do mercado nas esferas mais diversificadas de nossas vidas, notadamente no âmbito da subjetividade. A ambição de envolver o consumidor ou telespectador como parceiro e fă, torna indispensável problematizar a participação dita espontânea nas redes sociais. Nesse sentido, a mobilização do espectador-internauta pode ser pensada no contexto das estratégias de produção do produto midiático de maior valor agregado na televisão brasileira: a telenovela. 


\section{Referências bibliográficas}

ANDREJEVIC, Mark. (2008).Watching television without pity: the productivity of online fans. Television \& New Media, 9(1), 24-46.

ANTONACCI, Andrea; BACCEGA, Maria Aparecida. (2012). Cheias de charme: um estudo sobre transmidialidade e produçáo de interatores à luz da narrativa televisiva. Anais do XXXV Congresso Brasileiro de Ciências da Comunicação (INTERCOM).

BACCEGA, Maria Aparecida. (2009). Inter-relaçóes comunicação e consumo na trama cultural: o papel do sujeito ativo. Em: CASTRO, Gisela G. S. e TONDATO. Marcia P. (Orgs.). Caleidoscópio midiático: o consumo pelo prisma da comunicação. 2 - 30. E-book disponível em http://ppgcom.espm. br/images/docs/caleidoscopio_midiatico.pdf (acesso em 30 abril, 2013)

BOSSHART, Louis; HELLMÜLLER, Lea. (2009). Pervasive entertainment, ubiquitous entertainment. Communication Research Trends, 28(2), 3 - 19.

CANDIDO, Fabiano. (2011). Globo exige que YouTube exclua novelas. Exame.com, 16, julho. Matéria disponível em: http:/exame.abril.com.br/ tecnologia/noticias/globo-exige-que-youtube-exclua-novelas (acesso em 30 de abril, 2013).

CASTELLS, Manuel. (2009). Communication power. New York: Oxford University Press.

CASTRO, Gisela G. S. (2012). Notas sobre a inserção da telenovela brasileira na cibercultura. Revista Comunicaión, 1(10), 32 - 41. Disponível em: http://www.revistacomunicacion.org/pdf/n10/mesal/003.Notas_ sobre_a_insercao_da_telenovela_brasileira_na_cibercultura.pdf (acesso em 30 de abril, 2013).

. (2012a). Screenagers: entretenimento, comunicação e consumo. Em: BARBOSA, Livia (org.). Juventudes e geraçôes no Brasil contemporâneo. Porto Alegre: Sulina, 61-77.

- (2012b). Cheias de Charme: a classe trabalhadora no paraíso da cibercultura. Ciberlegenda, 27, 59-69.

. (2012c). Entretenimento, sociabilidade e consumo nas redes sociais: cativando o consumidor-fă. Fronteiras - estudos midiáticos, 14(2): 133-140.

CHAO, Vanessa. (2013). Brazil: the social media capital of the universe. The Wall Street Journal. http://online.wsj.com/article/SB100014241278873233011 04578257950857891898.html (acesso em 30 de abril 2013)

CRUZ, Renato. (2013). Brasil vira a capital da mídia social. O Estado de São Paulo, 3 março, Economia \& Negócios, p. 88.

FORD, Sam, DE KOSNIK, Abigail e HARRINGTON, C. Lee. (2013). The survival of soap opera: transformations for a new media era. Kindle Edition. JENKINS, Henry; FORD, Tom e GREEN, Joshua. (2013). Spreadable 
media: creating value and meaning in a networked culture. N. York: NYU Press.

MARTÍN-BARBERO, Jesús. (2008). A mudança na percepção da juventude: sociabilidades, tecnicidades e subjetividades entre os jovens. Em: BORELLI, Silvia, FREIRE FILHO, João. (Orgs.). Culturas juvenis no século XXI. São Paulo: EDUC.

MASCARENHAS, Alan e TAVARES, Olga. (2012). Transmídia em telenovela: Cheias de charme e de transmidialidade? Anais do XXXV Congresso Brasileiro de Ciências da Comunicação (INTERCOM).

FOLHA DE S.PAULO. (2013). Redes sociais mudam a forma de ver TV. TEC, F3, 22 abril. (matéria não assinada).

REGO, Aline S. (2012). Cheias de charme: televisão, interatividade e produção de subjetividade na novela das sete. Anais do XXXV Congresso Brasileiro de Ciências da Comunicação (INTERCOM).

SARKIS, Marcelo. (2013). Um olho na TV, outro no computador. Portal Zero Hora. 28 abril.

SODRÉ, Muniz. (2002). Antropológica do espelho: uma teoria da comunicação linear e em rede. Rio de Janeiro: Vozes.

SCOLARI, C. (2011). entrevista concedida a MUNGIOLI, M. Cristina. A construção de mundos possíveis se tornou um processo coletivo. Matrizes, 4(2), 127-136.

(2008). Hipermediaciones: elementos para una teoria de la comunicación digital interactiva. Barcelona: Gedisa Editorial.

TARAPANOFF, Fabíola P. A. e FERNANDES, Julio C. (2012). Reflexos de uma ascensão: o imaginário da classe $\mathrm{C}$ nas novelas 'Cheias de Charme' e 'Avenida Brasil'. Anais do XXXV Congresso Brasileiro de Ciências da Comunicação (INTERCOM).

TORREGLOSSA, Siliva e JESUS, Adriano M. V. (2012). Estudo sobre fấs na telenovela brasileira e sua representação modelar em 'Cheias de charme'. Anais do XXXV Congresso Brasileiro de Ciências da Comunicação (INTERCOM).

PORTAL GLOBO.COM. Saiba mais sobre a importância da carteira assinada. http://tvg.globo.com/novelas/cheias-de-charme/TrabalhadorDomestico/index.html (acesso em 30 de abril, 2013). 